Journal of Social Sciences (COES\&RJ-JSS)

ISSN (E): 2305-9249 ISSN (P): 2305-9494

Publisher: Centre of Excellence for Scientific \& Research Journalism, COES\&RJ LLC

Online Publication Date: $1^{\text {st }}$ April 2016

Online Issue: Volume 5, Number 2, April 2016

http://centreofexcellence.net/J/JSS/JSS\%20Mainpage.htm

\title{
FEMALE EMPOWERMENT: \\ THE IMPLICATIONS FOR DEMOCRACY \\ AND DEVELOPMENT IN NIGERIA
}

Dr. Mrs. Josephine Azuka Onyido

Department of Educational Foundation

Faculty of Education

University of Port Harcourt

azukaonyido@yahoo.com

$+2348033089056$

\begin{abstract}
:
Democracy is a system of government that seeks to involve, entrench and demand the participation of all stakeholders. It seeks to bring about societal development through equal participation of stakeholders in infrastructural and economic development. The Nigerian democratic experience has been plagued by interruptions by military regimes, political violence, corruption and notably the discrimination and marginalization of women. This therefore, is not the essence and purpose of democracy and consequently affects the development of the society, economy to mention a few. Hence, to attain equal stakeholder's participation with a view to eradicating these challenges there is need, for female empowerment to be encouraged so as to stimulate participation and decision making in the democratic terrain. This paper therefore, seeks to critically analyze and discuss the effect of female empowerment on the Nigerian democratic experience. It highlights the importance of gender/female empowerment and history of the Nigerian democratic experience, while stressing the importance of gender empowerment for democratic stability and societal development. It finally concludes that addressing female/gender empowerment and tackling the challenges of women participation in politics would go a long way in ensuring democratic stability and entrenching democracy in Nigeria.
\end{abstract}

Keywords:

Female Empowerment, Democracy, Societal Development.

Citation:

Onyido, Dr. Mrs. Josephine (2016); Female empowerment: The implications for democracy and development in Nigeria; Journal of Social Sciences (COES\&RJ-JSS), Vol.5, No.2, pp: 96-103. 


\section{Introduction}

Nigeria which obtained its Independence in 1960 and became a republic in 1963 currently operates a democratic system and although, democracy is assumed to be a system of government that seeks to involve equal participation of stakeholders in decision making so as to be able to achieve economic, societal development through the use of human and natural resources. Considering however, the vast human and natural resources available to the Nigerian government there still exist a big gap between the poor and the rich in Nigeria. The country continues to suffer from lack of social amenities, inflation, insecurity, slow economic development, discrimination against women in decision making and participation in the democratic terrain. This probably explains the rising despondence among masses towards the Nigerian government and could pose a threat to the continued sustenance of democracy in Nigeria (Eliagwu, 2005). Segun (2013) Highlights, that the unemployment and insecurity situation, has greatly affected the democratic experience in Nigeria. Hence, for the Nigerian democratic experience to be able tackle the issues currently plaguing the country there is need for equal participation of both genders in decision making. Scholars have continue to stress that men are given preference in decision making and participation in the Nigerian democratic terrain and this could possibly be hampering the ability of women contributing to societal development and transformation (Ngara \& Ayabam,2013). This according to Umar \& Abdullahi, (2007) is borne out of the sentimental bias women suffer in the African culture.

\section{The Concept of Democracy}

Scholars have continued to debate the meaning of democracy; this is as result of the complications that have come up because of the varying concepts of democracy being practiced globally. According to Sodaro (2001) democracy is simply the right of people to determine who governs them, hold them responsible for their actions and impose legal limits of the authority of the government by guarantee certain rights and freedoms to their citizens. According to Segun (2013) democracy means governments that have been established by and with the consent of the people most times by the constitution. He further stated that the leaders are chosen by the people in an election. Adeyemo (2009) further posits that the autonomy of the aspiration and wishes of the electorate in decision making is known as democracy. This confusion led to Dahl's conviction that there is no perfect democracy and should simply be a polyarchy where the government is concerned with meeting the needs of its citizens (Dinneya, 2006). Hence it can be deduced that democratic government should reflect the aspirations of the people and the people have the certain right that those who are voted into electable offices should respect while maintaining the right to vote and be voted for via elections.

\section{EMPOWERMENT}

The concept of empowerment faces disparity in viewpoints however; scholars have agreed that empowerment is simply about having the power to participate or to exercise significant influence in organizational process. It is equally the right to be heard, involved as well as the right to question, resist or checkmate arbitrary policies (Umar \& Abdullahi, 2007). As such it can be deduced that empowerment is a multifaceted process which entails changes in psychological, cultural, social and political aspects of the lives of people so as to remove hindrances that may alienate them or mitigate against the development of human potentials and talents that are essential for human development.

Politically with regards to women empowerment it simply implies the setting of workable strategies that are aimed at equipping them to have the capacity to be self reliant and be able to participate and contest for political positions. This will involve women, engaging 
in activities they may not have previously being equipped to do so and thereby increasing the possibility of them improving their economic status. Females account for ...of the Nigeria's' population, hence, it must be emphasized that neglecting this large proportion of its population may serve as impediments to national development and progress.

However, in spite of the recognitions that women should be empowered so as to attain gender equity and improvement in their social status, women in Africa are still subjected to abuse and denial of their inherent social, human and political rights (Naake, 2004). Women who pursue career in politics are often stigmatized, disregarded or discriminated by the society. In the Nigerian context, women are perpetually condemned to playing roles domestically and sexually. Their capacity for wage earning is relatively curtailed as such, any woman who breaks this tradition is considered rebellious, disrespectful and too independent.

\section{History of Nigerian Women in Democracy in Nigeria}

During the pre-independence era, in Nigeria women slowly begun to emerge who did not fit this traditional African roles placed on them by the society and begun to partake in politics and decision making. Such women include, Mrs Janet Mokelu, Mrs Margeret Ekpo and Ms. Young were members of the Eastern House of Assembly. Also worthy of note in this era include Funmilayo Ransome Kuti and Haija Gambo Sawaba. Nigeria at that time actively participated in UN conferences such as the United Nation's Decade for Women, 1993 Vienna Human Rights Conference, the 1995 Copenhagen Summit on Social Development and Beijing World Conference. Thus it can be argued that the activities of these women played a critical role in raising awareness on the need and the right of women to have a say in the present day political terrain in Nigeria particularly, since the introduction of the structural adjustment policies (Onwubiko, 2012). Today, many women have established themselves in different spheres of life they include; Chioma Ajunwa, Amelia Okoli, Blessing Okagbare (Sports) Patience Ozokwor, Genevieve Nnaji, Omotola, Onyeka Onwenu (Entertainment); Prof Francisca Okeke, Prof Grace Alele Williams (Education); Prof Adenike Grange, Dr. Olufunmilayo Falusi Olupade (Medicine), keme achikwe, Diezani Allison-Madueke, Haija Maina (Politics) Haija Bola Shagaya, Folorunsho Alakija (Business) to mention a few.

\section{Impact of Female Empowerment on Democracy}

Democracy no doubt places higher expectations from the government. Okoronkwo (2001) highlights that there is need for the government to promote equal gender participation in public decision making so as to foster peace and a more transparent/inclusive government. .... Argues that until women are given the opportunity to initiate and execute public policies and legislation that cannot effectively tackle the challenges facing them. Women have setup more associations aimed at raising awareness and seizing any opportunity given to them to assert their roles and advance their course. It is however regrettably to note that although women constitute a greater percentage of registered voters in Nigeria they are yet to experience full representative positions (Okoronkwo-Chukwu, 2013). Onwubiko (2012) posits that women are regarded as the currency to which political and economic alliances are cemented. As such, this suggests that women take preeminent roles in governance. However, this is not the case as In 1999, the general elections saw only 181 positions won by women out of 11,881 available positions (Samuel \& Segun, 2012). In 2003, in states like Oyo, Sokoto, Zamfara, Kano, Ebonyi, Jigawa, Katsina, Nassarawa, Kebbi, Cross River and Adamawa no woman was elected into any seat (Agbalajobi, 
2010). In the 2007 elections, a total of 1532 seats were available with 1200 women contesting only 93 emerged winners including 6 Deputy Governors (Asaju \& Adagba, 2013).

It is important however, to note that despite the poor performance of women in elections in Nigeria, women have performed credibly well in every sector of the economy as reflected by Political appointees made by various administrations Prof Dora Akunyili, former Director General, National Food and Drugs Control (NAFDAC), Ndi Okereke Onyuike, former Managing Director of the Nigerian Stock Exchange; Dr. (Mrs.) Obiageli Ezekweseli, Mrs Evelyn Oputu, Managing Director of Nigerian bank of industry, Prof (Mrs.) Grace Alele Williams, former Vice chancellor, University of Benin and Dr OkonjoIwela who as minister for finance helped the nation reduce its external debts. Their enormous contributions to national development paved way for reevaluation of the roles of Nigerian women as a result of their roles which include; fostering unity and cohesion among diverse ethnic groups and associations in Nigeria through inter-ethnic and inter tribal marriages, ensuring conflicts are resolved amicably using their motherly attributes. In-addition, majority of the labour that sustain life-growing food, cooking, caring for the elderly, managing the house and raising the children is done by the woman (Onwobiko, 2012). Mohammed \& Abdulquadri (2012) posits that women are responsible for carrying out $50-60 \%$ of the Nigeria's' food processing, agricultural and animal husbandry activities even with the fact they are challenged by lack of resources and funds (Akpalaobi, 2011) hence, contributing immensely towards social and national development. In addition, women in Nigeria have a greater numerical advantage in the Nigerian population as such, they have the potential of turning an ailing economy at the local, state and national levels through their ability to plan, organize and their inbreed economic strength to overcome obstacles posed by the environment, culture to mention a few (Asaju \& Adagba, 2013).

The contributions of women to social and national development cannot be ignored as it continues to impact massively on the national polity and economy and successive administrations have responded positively to encourage such participation with the establishment of parastatals aimed at improving women participation in decision making and politics. These include the National Council of Women's Societies (NCWS). Equally a lot more women are being appointed into key political positions such as ministers, Permanent Secretaries and Judges. This will go greatly promote gender equality and equal stake holder participation and as such, reduce agitations and frictions that may occur if all parties are not carried along or do not feel the impact of democracy on their lives. Nevertheless, according to a UNDP report, women participation in politics and decision making is still inadequate (Asaju \& Adagba, 2013). The British Council Report (2012) indicates that Nigeria currently stands at 118 out of 192 countries with gender disparity lagging far behind countries like South Africa (43\%) and Rwanda (65\%).

Challenges facing women participation in politics

1.Cultural and religious discrimination

2.Lack of confidence

3.Funds

4.Marginalization in leadership of political party

5.Political violence

6.Illiteracy

7.The perspective of Women towards politics 
1.Cultural and Religious discrimination: women are discouraged from participating in politics even from childhood they are taught to be quiet, submissive by their fathers, brothers and mothers. They are made to accept that their views would not be listened to (Muoghalu \& Abrifor, 2012) hence; participating in politics would be seen as breaking out of societal expectations and thus leading to discrimination. Similarly, religion is also a barrier in women participating in politics. In some religions women are considered second class citizens and this also affects how women can partake in decision making and politics. For instance, Muslims in northern Nigeria, try to bar women from participating in politics likewise the Christian faith do not accord women the same equality.

2.Lack of confidence: one of the greatest challenges facing women in politics today is the lack of believe in themselves. According to ... women lack confidence in their ability to lead or make decisions on their own. In most cases, they believe politics in for men and even when they participate they do not have the confidence that they are capable of leading. Although, it must be highlighted that factors such as envy, jealousy and other problems hinder women from following their fellow women this often give men the upper hand when mobilizing for supporters (Ngara \& Ayabam, 2013) for instance, the case of Mrs Sarah Jubrin, who contested against President Goodluck Jonathan and Alhaji Atiku Abubakar in the PDP presidential primaries in the build up to the 2011 general elections. At the end of the exercise, Sarah Jubrin pulled only one vote which obviously was her own.

3.Funds: participating in politics is an expensive venture which requires a huge financial involvement, majority of women in Nigeria are not capable of such expenses. This factor mitigates against them as about $90 \%$ of Nigerian women live below poverty level and in most cases they lose out in elections or afford to buy party nomination forms (Yahaya, 2012).

4.Marginalization in leadership of political party: Ngara \& Ayabam (2013) highlights that most of the political hierarchies are dominated by men, the considerable limited financial situation of women contribute to this, as well as their lack of confidence in themselves. These in turn affect their powers and influence within the party structure hence during party nomination or decision making they are unable to assert themselves or even protect the interest of women.

5.Political Violence: Kolawale (et al 2012) asserts that political violence is a major contributing factor that serves to discourage women from participating in Nigerian politics. A typical electoral process in Nigeria is characterized by bloodshed and mayhem and most women do not have the stomach for such. Luka (2012) further stresses that the spate of political assassination, political thuggery have caused women to dread and avoid politics.

6.Illiteracy: A survey by UNICEF revealed that a major challenge faced in Nigeria is illiteracy or low level of education. Hence, this has posed a major disadvantage for women who seek to participate in politics. Another survey carried out by the National Planning Commission revealed that $50 \%$ of women had no formal education (Okpilike \& Abamba, 2013). These figures greatly explain why women are challenged to participate and contest for elective positions. 
7.The Perspective of Women towards Politics: In Nigeria, politics is seen as a dishonest profession, it is associated with scandals and bribery as the common perception of politics is that it is dirty practice reserved for people who have questionable integrity and little or no regard for due process and the law. Hence, women who participate in politics are seen to have such characters. This has consequently, discouraged a lot of women from participating in politics in Nigeria so as to avoid the blot associated with politicking.

\section{Recommendations}

-Women leadership organizations and relevant stake holders should continue to advocate the legislations that favour protection of women from abuse and discrimination.

- Government and female rights organizations should continue to empower and train women so as to become independent and politically relevant.

-Government and non-governmental bodies should provide avenues that would encourage and build networks of solidarity among women.

-Government should pass legislations that seek to encourage equal stake holder participation in decision making and politics.

-Government should continue to review legislations and policies related with female participation in politics.

-Women should shake of the shackles of discrimination and strive to have a voice of their own.

\section{Conclusion}

The transition from military to democracy in Nigeria has greatly improved that stakes of women in politics. It cannot be argued that women are highly instrumental in sustaining democracy as they contribute enormously to economic and societal growth. However, women participation in politics and decision making remain largely affected by a number of challenges such as cultural and religious discrimination, lack of confidence, funds, marginalization in leadership of political party, political violence, Illiteracy, the perspective of women towards politics has been identified as responsible for this. In spite of these, women continue to make tremendous strides and achievement since 1999 and the number of women engaging in politics continue to rise as such indicating a brighter future for women and democracy if these recommendations are made to fast track female empowerment and participation in politics.

\section{References}

Adeyemo. A. (2009). Paris, Gains of a Decade of Democracy, This Day Newspaper, May 29, p. 25

Agbalajobi, D. T. (2010) "Women's Participation and the Political Process in Nigeria: Problems and Prospects" African Journal of Political Science and International Relations Vol. 4(2): 75-82.

Akpalaobi, B. N. (2011) "The Dynamics of Sexual Politics in Nigeria: A Catalyst for Gender Bias" Journal of Emerging Trends in Educational Research and Policy Studies Vol. 2(6): 471-478.

Allen, F. (2009). From "Authoritarian Rule" to "Democracy" in Nigeria: Citizens" Welfare a Myth or Reality. Journal of Alternative Perspectives in the Social Sciences, l(2), 152-192.

Asaju, K. and Adagba, S. O. (2013) "Women Participation in National Development in Nigeria: Imperative of Education" Journal of Public Administration and Governance Vol. 3(1): 57-69. 
British Council (2012) Gender in Nigeria Report: Improving the Lives of Girls and Women in Nigeria Issues, Policies, Action. 2nd Edition.

Chiejina, O. (2011) "Women and Politics in Nigeria" Journal of Research and Development Vol. 3(1): 159-164.

Dike, F. I. (2012) Nigeria: Enhancing Women Participation in Politics and Governance, Matters Arising Jabi, Abuja: Fairdeal Press Ltd.

Elaigwu, J. J. (2005). "Crises and Conflicts Management in Nigeria Since 1980" in Yakubu, A.M.,

Fabiyi, O. (2015). PDP Ask IGP to probe attacks on Imo Widows, Punch Newspaper, February 22. Accessed Online [http://www.punchng.com/news/pdp-asks-igp-to-probeattacks-on-imo-widows/

Fasoro, J.O. (2015) "Patronage and Tokenism: The Bane of Gender Justice in Nigeria" International Journal of Arts and Commerce. Vol. 4(2).

Gouws, A., \& Shireen, H., (2011), The Power to Change: Women's Participation and Representation in Africa, Background Paper Prepared for HBS Engendering Leadership Project, Kapstadt: Heinrich-Böll-Stiftung.

Index Mundi: Nigeria Demographics Profile 2014. Accessed Online on the $2^{\text {nd }}$ of January 2015 from[ http://www.indexmundi.com/nigeria/demographics_profile.html]

Kolawale, T. O., Abubakar, M. B., Owonibi, E. and Adebayo, A. A. (2012) "Gender and Party Politics in Africa with Reference to Nigeria" Online Journal of Education Research Vol. 1(7): 132-144

Luka, R. C. (2011). Women and political participation in Nigeria: The imperatives of empowerment. Journal of social sciences and public policy, Vol.3, 24-37.

Mohammed, B. T. and Abduquadri, A. F. (2012) "Comparative Analysis of Gender involvement in Agricultural Production in Nigeria" Journal of Development and Agricultural Economics Vol. 4(8): 240-244.

Muoghalu, C. O. and Abrifor, C. A. (2012) "Urban Poor Women and Governance in Nigeria" European Scientific Journal Vol. 8(5): 176-185.

Naake, Anthony Y (2004), "Breaking the Silence about Domestic Violence: Communication for Development in Northwestern Ghana", Gender and Behaviour, volume 4 number 2, pp. $782-794$.

Nelson, E. E. (2012) "Democracy and the Struggle for Political Empowerment of Women in Nigeria" International Journal of Advanced Legal Studies and Governance Vol. 3(1): 85-99.

Ngara, C. O., \& Ayabam, A. T. (2013). Women in politics and decision-making in Nigeria:Challenges and prospects. European Journal of Business and Social Sciences, 2(8), 47-58.

Oghale, E. Women leadership and its relevance to National Development in the $21^{\text {st }}$ Century: Unizik Journal of Arts and Humanities www.ajol.info > Journal Home > Vol 15, No 2 (2014)

Okoronkwo, C. C. (2001) Gender Inequalities in Nigerian Politics Dissertation in Partial Fulfilment of the Requirement for the Degree of Masters of Arts in Corporate and Public Communication, Seton Hall University.

Okoronkwo-Chukwu, U. (2013). Female Representation in Nigeria: The Case of The 2011 General Elections And The Fallacy Of 35\% Affirmative Action. Research on Humanities and Social Sciences, 3(2), 39-46.

Okpilike, F. M. E. and Abamba, G. O (2013) "Sociological Explanations of Male Dominance in Nigerian Party Politics: Implications for Education" British Journal of Education, Society and Behavioural Science Vol. 3(2): 154-162. 
Onwubiko, C. P. C. (2012) "Empowerment of Nigerian Women towards National Development" Journal of Resourcefulness and Distinction Vol. 2 (1): 68-78.

Samuel, O. and Segun, J. (2012) "Gender Relations in Nigeria's Democratic Governance" Journal of Politics and Governance Vol. 1(2/3): 4-15.

Segun, J. (2013). Democracy and Violent Conflicts in Nigeria: Implications for National Development An International Multidisciplinary Journal, Ethiopia Vol. 7 (3), Serial No. 30, July, 2013.

Sodaro, M. J. (2001). Comparative Politics A Global Introduction, New York: McGrawHill

Tashi (2000) "The Potentials of Women in Political Development: The Case of Plateau State" Multidisciplinary Journal of Research Development Vol. 2(1): 95-106.

Umar, M. Z. \& Abdullahi, A. (2007). Women Empowerment And Nigerias Development: Perspectives, Challenges And Prospects. Journal of Research in National Development. Vol. 5, No. 2.

Yahaya, A. (2012) "Muslim Women and Political Participation in Nigeria" Paper Presented at the Nigerian Muslim and Democracy Conference Abuja. 